To appear in Justin McBrayer and Trent Dougherty, eds., Skeptical Theism: New Essays (Oxford: Oxford University Press, 2013)

\title{
Skeptical Theism and Skeptical Atheism
}

At the heart of skeptical theism are claims such as these three, defended by Michael Bergmann (2009):

S1 We have no good reason for thinking that the possible goods we know of are representative, relative to the property of figuring in a (potentially) God-justifying reason for permitting such things as hiddenness or horrors, of the possible goods there are. ${ }^{\mathrm{i}}$

S2 We have no good reason for thinking that the possible evils we know of are representative, relative to the property of figuring in a (potentially) God-justifying reason for permitting such things as hiddenness or horrors, of the possible evils there are.

S3 We have no good reason for thinking that the entailment relations we know of between possible goods and the permission of possible evils are representative, relative to the property of figuring in a (potentially) God-justifying reason for permitting such things as hiddenness or horrors, of the entailment relations there are between possible goods and the permission of possible evils. ${ }^{\text {ii }}$

Bergmann and other skeptical theists find claims like these to be very plausible - even commonsensical. They think, moreover, that the atheist who is promoting one or another argument from hiddenness or horrors should see them in the same way, and thereby be led to 
give up his argument. The central idea of skeptical theism is regarded as non-discriminatory, no respecter of persons, available to just any reasoning person at all.

Skeptical theism is thought by its advocates to be non-discriminatory in another way, too. As already suggested, it is supposed to work for just any argument from hiddenness or horrors. In a recent piece, Bergmann applies his skeptical theses to arguments from William Rowe, Paul Draper, and myself, arguing in each case that, given such truths as S1-S3, we are simply "in the dark" about something we need to know if the argument is to be successful (2009).

It seems to me that skeptical theism had better have this reach if it wants to do important work for theism in philosophy, for a theistic device that deactivates some threatening arguments from hiddenness or horrors but not all of them will leave atheism untroubled (the atheist, after all, only needs one argument to work). But I believe that it lacks this reach. Some robust forms of atheistic reasoning from hiddenness or horrors are untouched by it, at least to this extent: that they are not prevented by it from providing justification for the atheist to be an atheist. ${ }^{\text {ii }}$ This is argued in section I. In section II we see that skeptical theism is non-discriminatory in a way that might not be welcomed by its advocates, in that it suggests a new way for the atheist to question the theist's support for his own belief. If skeptical theism undermines some ways of justifying atheistic belief, skeptical atheism undermines perhaps the most important way of trying to justify theistic belief, using the theist's own form of reasoning to do so, while leaving the aforementioned atheistic arguments unscathed. Finally, in section III I expose another way in which we might speak of a 'skeptical atheism' alongside skeptical theism, growing out of the discussion of the previous section. Paradoxical as it may seem, an investigative atheism may be embedded in a wider skepticism, and may use the form of reasoning employed by skeptical theists to realize new ways of perpetuating at least doubt about theism and, more positively, to 
communicate an urgent message: that a very great deal of investigation remains to be done into alternatives to theism as an understanding of the Divine. The upshot? Skeptical theism utilizes a form of reasoning that not only lacks the reach that would make it really powerful in the hands of theistic philosophers, but potentially possesses quite formidable investigative powers when placed in the hands of atheists.

\section{I.}

Let's begin by considering how atheistic reasoning may acquire immunity to skeptical theism. I suggest that the atheist should allow that skepticism is indeed often appropriate, but follow up with the observation that belief and confidence are sometimes appropriate, too, and that some of the propositions available to an atheist concerned with hiddenness or horrors (a) are ones about which she is appropriately believing and confident and (b) clearly entail that no God-justifying reason of the needed sort exists.

Notice that we can illustrate the first part of this answer with what the skeptical theist himself is confident and believing about, despite his skepticism: propositions about how he should live his life, for example, or about not being a brain in a vat (Bergmann 2009). And presumably he is - at least in the present dialectical situation - not inclined to question the idea that the atheist is likewise rightly confident about various such things.

Well, in the same way, I would suggest, it begs to be noted that although certainly not equipped with a comprehensive grasp of the domains of value and modality, and quite in the dark about many things, we may nonetheless be the recipients of various specific insights about value and modality that generate premises and inferences which an atheist can employ. As inquirers, 
desiring to achieve fundamental understanding, whether that be theistic in nature or not, we should look for such stray instances where light pierces the darkness. Certainly we should not delight in darkness! And I would suggest that if we seek, we will find.

There is some a priori reason to suspect that such will turn out to be the case in the present area of concern. This is because the claim of traditional theism is that the ultimate reality is a person, very different from us in various ways, certainly, but in many ways similar too. I don't think this is always remembered by skeptical theists, who sometimes write as though we were talking about the more general idea I have elsewhere called ultimism, instead of about theism; as though we were forced to operate without much of an idea as to how metaphysical, axiological, and soteriological ultimacy are instantiated if there is a God. Given the quite detailed filling out of ultimism that theism represents, we do have a few ideas about such things that should be regarded as reliable. Theism describes the Ultimate in familiar terms, and so even if there may be much that we are quite unfamiliar with in the realms of value and modality, and even if a God would be familiar with many such things while we are not, what we do know on relevant matters may strongly seem to us to entail that things would in some way be different, in respect of hiddenness and horrors, than in fact they are, if there were a God.

I have defended such claims in various places. Because of our access to truths about, among other things, the love of persons, we can learn that a perfectly loving personal God would never permit nonresistant nonbelief, which manifestly exists. And because of our access to truths about, among other things, the empathy of persons, we can learn that a perfectly empathetic personal God would never permit horrors, which also manifestly exist. I will not repeat all the details of the arguments, but they include reference to such obvious-seeming propositions as 
Because God is unsurpassable greatness personified, persons who grow ever deeper into God realize their deepest good and Because God is infinitely deep and rich and exclusively good, endless opportunities for persons to grow ever deeper into God arise even where God has prevented horrors altogether and also If finite persons can achieve their deepest good without horrors being permitted, then an unsurpassably empathetic God will not permit horrors.

Now in response to such claims the skeptical theist may want to suggest that some unknown valuable dimension of growth into God might, for all we know, require that horrors be permitted. But this may seem to the atheist a case of implausible reaching, which reason alone can no longer be said to support (see Schellenberg 2007, pp. 254-256). Or perhaps the skeptical theist will want to argue for the possibility of relevant goods external to any such relationship which God might find attractive. But here again it may seem to the atheist that we have to forget what theism has got us talking about in the first place - an ultimate person - to be impressed.

Consider by way of analogy a single man who marries and has children: Does this behaviour not rightly constrain the goods he is willing to pursue, at least insofar as he is a loving husband and father? Though when he was on his own he spent time with many female friends and was otherwise preoccupied with his own wide-ranging pursuits, traveling to Europe for months at a time, shifting from place to place and from one activity to another, now things are different, and quite naturally and rightly so. Now he has a family to help provide for, to support in emotional and financial ways. He can't just leave for Greece or Spain any time he wants to indulge his own interests - better, he has new interests which lead him happily to say no when invitations to do such things arise. Similarly with God, if God is to be regarded as a loving person - an ultimately loving person - who has created vulnerable finite persons to be the object of Divine love. The God described by skeptical theists who may, for all we know, have purposes 
quite unrelated to us that require hiddenness from us or horrors for us is not an ultimately loving and kind and empathetic being. If a person at all, such a God would be comparable to a delinquent father or mother who simply can't or won't live up to the demands taken on board when the commitments of marriage and family are entered into.

The atheist, in my view, should say that there is a large medley of such things to be said in which may be found propositions concerning horrors or hiddenness entailing the nonexistence of a personal God - propositions and entailments that seem as obvious to him, that are as much a matter of common sense, perhaps (if we can think of the latter as extending to necessary truths), the longer and the more intently he reflects on them, as the claim that we may be in the dark on many things regarding modality and value. There is therefore absolutely nothing immodest or unduly cognizant of our cognitive limitations in his endorsing those views. Indeed, by accepting both those views and the most general and plausible content of the skeptical theist's cautions, the atheist can claim to come out further ahead, in the world of inquiry, with a more balanced stance and one more sensitive to the results of wide reflection than would otherwise be possible. ${ }^{\text {iv }}$

In his (2009) Bergmann says that he doesn't see how love or infinite resourcefulness, which I have also emphasised, are relevant to whether there is an outweighing good that might successfully draw God's attention, given that there being such a good would not be a contingent but a necessary state of affairs. In my view the strongest atheistic arguments make such an observation irrelevant when, against the backdrop of undeniable claims about God's love and empathy, they distinguish outweighing goods from our deepest good in relationship with God, or when, in connection with the infinite richness and resourcefulness of God, they distinguish the goods emphasised by critics from the broader types of good they instantiate, all of which can be met with in relationship with God. But however that may be, in the present context the demurral 
of skeptical theists is compatible with the failure of their argument. For what Bergmann and others don't see needn't prevent the atheist from being convinced, and justifiedly so, if he thinks he clearly sees that God would not permit horrors or hiddenness, in the context of both the skeptical theist's arguments and such reflections as were outlined earlier in this section. These reflections, it is worth noting, take us far beyond the famous 'noseeum' inferences of William Rowe's original arguments, to which skeptical theism was originally directed (see Rowe 1979).

Suppose the skeptical theist grants, for reasons of the sort I have given, that his reasoning may not remove the atheist's justification for believing that atheism is true. This is at the same time an admission that skeptical theism lacks, as I have put it, the reach that would make it really powerful as a theistic form of reasoning in philosophy. For it cannot entirely stamp out the blaze of atheistic reasoning. Skeptical theism, I suggest, is going to seem most powerful where one or other of three conditions is realized: (a) where the atheistic reasoning examined is exclusively probabilistic, perhaps depending on simple inductive inferences about reasons for evil unsupplemented by additional truths about the Divine nature, of the sort once found in Rowe; (b) where parties to the debate share an undernourished conception of God, without sufficient content to entail such a thing as that a God would have an aversion of the relevant sort to horrors or hiddenness; or (c) where the conception of God that dominates is nourished by ideas from theistic religious traditions reflecting centuries of thinking about God on the assumption that God exists, and therefore on the assumption that a God would permit both horrors and hiddenness. Philosophers of religion who examine atheistic reasoning should resist all three of these conditions, at least within the precincts of philosophy. What we have seen, in effect, is that if they do, they will find the philosophical force of skeptical theism against such reasoning greatly attenuated. 
II.

Suppose that the claim defended in the previous section is correct. This is compatible with the theist for one reason or another being justified in rejecting for herself the arguments from horrors or hiddenness that, I have said, may justify the atheist's belief. Let's suppose that she is so justified. Still, there is a problem for the theist's belief that arises in this connection. For if there is a skeptical theism that undermines certain ways of justifying atheistic belief for the atheist, such as Rowe's original evidential argument from evil, there is also a skeptical atheism that can undermine the theist's ways of justifying theistic belief for herself. This, then, is the second point to be made in an assessment of the force of skeptical theism. Skeptical theism succeeds, to the extent that it does, only by empowering skeptical atheism, giving to the atheist an argument form she can use against the theist's own basis or grounds for being a theist.

I want to focus here on experiences apparently of God. In his (2009) Bergmann concedes that design arguments for theism are imperilled by skeptical theism. Perhaps other theistic arguments will be similarly affected. I will leave this for others to consider. For all such results in relation to theistic arguments only give skeptical theists an extra reason to do what perhaps most theists in philosophy are already doing: emphasise non-propositional sources of justification for belief. What I have in mind, in particular, are the sorts of justification for theistic belief defended by William P. Alston in his influential (1991) and by Alvin Plantinga in his equally influential (2000). Experiential accounts of theistic belief and its justification of the sort defended here have become more and more common in theistic philosophy in recent decades.

So how can we bring skeptical theism into conversation with them? One way would be to propose a new skeptical thesis, which the atheist may say should be as acceptable to the theist as she claims S1-S3 ought to be to Rowe: 
S4 We have no good reason for thinking that the considerations opposing the epistemic force of religious experience we know of are representative, relative to the property of (potentially) figuring in an undefeatable defeater of religious experience as justification for theistic belief, of the considerations opposing the epistemic force of religious experience there are.

There is, I suggest, no non-arbitrary way for the theist to discriminate between the matters addressed by S1-S3 and those addressed by S4 in relation to what she has reason to believe. If we are cognitively limited in a way that would make the first three propositions true, then the fourth is true as well: the cognitive limitations in question affect all the matters under considerations here if they affect any. Notice also, in this connection, that S4 is as 'theism-friendly' as Begmann's own theses, mentioned earlier, are 'atheism-friendly.' ${ }^{\text {v }}$ Good reason to believe in God is no more good reason to affirm representativeness here than good reason to believe in the nonexistence of God was good reason to affirm it there.

Let's look a bit more closely now at how Rowe can return the favour when the skeptical theist hands him her argument, thus becoming, in effect, a skeptical atheist. The bearing of facts about value and modality, which the skeptical theist already regards as rightfully generating skepticism, may be harder to see in this case. But it is there. It might be, for example (so the skeptical theist should reflect to herself), that what certain unknown truths would clearly show to anyone who beheld them is that great evils would necessarily be generated were God to be present to traditional theists in the ways they believe to be the case, at least at the present stage of human development - evils sufficiently impressive to prevent any God there may be from being 
present in those ways at this time.

On the basis of very similar reasoning, skeptical theists make their own case against atheistic arguments. Indeed, the skeptical theist may think it's enough just to say that a God's reasons would not be transparent to us. For example, in his response to Divine hiddenness Bergmann writes that "we're simply in the dark about whether (and how likely it is that) there are any God-justifying reasons for permitting a period of divine hiddenness" (2009, pp. 382-383). Now we've already seen how an atheist might successfully resist such a move - at least for herself. But the skeptical theist, naturally enough, accepts it. So we can respond: How long a period of divine hiddenness might God tolerate? Might the notion of divine hiddenness appropriately be broadened so as to include theists, in the sense that their experiences apparently of God, because of unknown Divine purposes requiring it and/or their own spiritual immaturity, are not of God at all? Suppose they are not of God in the relevant sense. If persistently and clearly presented with such a truth, any theist relying on religious experience would have an undefeatable undercutting defeater for such experience as justification for her theistic belief. As it is, she is in the dark about whether the relevant proposition is true. So she is in the dark as well about whether, more adequately positioned, she would have such a defeater. But surely to justifiedly believe that God exists in response to religious experience, she must believe that the facts of the case would not support such a defeater. If she cannot so believe, then this itself defeats her justification. It follows that she cannot justifiedly believe that God exists in this way.

Of course there is nothing to require that we restrict ourselves to unknown truths about value or modality in this connection. If there may be unknown truths about such things, it is hard to see why there might not be unknown truths in certain other, relevantly similar domains as well: should we expect our cognitive limitations to be so narrowly circumscribed as to prohibit 
this? Here it may be apropos to mention that, according to the best science, which theistic philosophers will wish to accommodate, we presently exist at a very early stage in the total period that may see intelligent life on our planet. We have at most 50,000 years of anything approaching careful thought about religion under our belts, and another billion years remain in which we - or species that come after us - may continue to think about such things (see Schellenberg 2013). Hence there may be many subjects on which we not only could but will do better than we have.

Perhaps - so the skeptical theist should reflect to herself - developments in psychology or neurophysiology, emerging long after we are gone, will reveal facts about the current human mind and/or brain inconsistent with such religious experiences as traditional theists today describe being veridical (undercutting defeater). Another possibility within a skeptically theistic frame of reference is that new and even more powerful and convincing theistic religious experiences, which advanced techniques of the future show to be veridical but inconsistent with God having been present to anyone in our own day in the way that God was thought to be present, will arise in the deep future (another undercutting defeater). Perhaps veridical experiences of God of sufficient clarity and intensity to justify belief in God are reserved for our more fully developed descendants. I would judge that any theist who believes such propositions as S1-S3 after fully making the transition from human to scientific timescales and properly appreciating the epistemic weight of distantly future Earthly possibilities will believe as well, insofar as reason has its way with her, that we have no good reason for thinking that events of the sort I have just described will never occur. S1-S3 describe what is the case for theists only if S4 does too.

How might the skeptical theist respond? Well, I suppose she might claim that her 
experience apparently of God is so intense and clear and enduring as to make it impossible for her not to respond to it believingly in the way that she does. One is inclined to think of excuse rather than justification in such a case. But we need not sort this out. For the religious experiences of theists in the actual world are almost never of that type. Plantinga admits as much in his (2000). Even where forceful, they are commonly not enduring. Nor are they frequently so discriminating as to have, precisely and clearly, theistic content alone, yielding to no other interpretation. Thus there is the opportunity to consider and be influenced by the defeater we have constructed from skeptical theistic materials. To the extent that such a defeater is resisted, we must wonder how seriously we should take the skeptical theist's criticisms of Rowe and others.

Perhaps the skeptical theist will at this point seek to defeat my argument by reductio. S4 appeals explicitly to the epistemic possibility of unknown evidence incompatible with the epistemic force of evidence (broadly construed) that theists might seek to use today. The skeptical theist may claim that a crucial shift is made when we transition from something like 'unknown goods' to something like 'unknown evidence.' The former is precise and localized, whereas the latter threatens to balloon out into a skepticism consuming all our beliefs. For which beliefs will not be impugned if we always have to worry about completely unknown counterarguments and experiences? Since the argument employing S4 implies the acceptability of such an unacceptable general skepticism, we have good reason to reject that argument.

I would suggest that there is indeed a broader skepticism to be developed here (it is the elephant in the room), and instead of fleeing from it, we should embrace it. I call it total evidence skepticism. To get a basic idea of this skepticism's distinguishing features, notice first that the total evidence relevant to a proposition, as here understood, is not my total relevant evidence or 
the total relevant evidence available or the total relevant evidence thus far assessed by human beings, or anything of the sort, but rather the total relevant evidence simpliciter: everything in the world that bears on the truth of that proposition (with the 'bears on' relation defined in such a way that a proposition cannot evidentially bear on itself) - in other words, the evidence relevant to its truth as it would be seen from a God's-eye view, from the perspective of omniscience.

With that as background, we may say that total evidence skepticism is the claim that, for many a proposition expressing a belief or potential belief of ours, we have reason to be in doubt, or skeptical, about whether the total relevant evidence supports that proposition. Even if our relevant evidence - the relevant evidence we have actually examined - supports the proposition, our evidence may not be representative of the total relevant evidence: for all we know, although the former supports it, the latter does not. Now a proposition is true only if the total evidence in my sense does support it. Thus where we have reason to be in doubt about whether the total evidence supports some proposition, we also have reason to be in doubt as to whether that proposition is true.

I have had something to say about this sort of skepticism elsewhere (Schellenberg 2007, 2013). And much more needs to be said. In particular, the related points about the deep future and our place in time touched on earlier in this paper need to be unravelled further. Here it will suffice to point out that if through investigation the skeptical theist comes to feel the force of something like total evidence skepticism, she will also see that the apparently troublesome feature of S4, treated here as paving the way for a reductio, ought rather to be embraced.

But we need to preempt a certain sort of response to this reasoning, a somewhat unsubtle response lurking already in the way I earlier phrased the objection here addressed. This response repeats the concern that it's 'all or nothing' - total evidence skepticism is also total skepticism, 
and should be expected to consume all our beliefs. Here I would urge calm. There is no reason to expect at the outset of such a discussion that no way of discriminating among propositions in respect of belief-worthiness, no criteria for sensible discrimination, can ever be found. Especially is this the case since total evidence skepticism, if linked to a proper appreciation of our place in scientific time, has to be seen as arising within inquiry. It is part of an attempt to further discovery of truths about the world by means compatible with our present primitivity. The inquiry to which it sees itself as attached springs not from belief of some controversial proposition to which it might itself be applied but from a love of understanding by which many of us are gripped, even in our primitivity. And although such love presupposes certain beliefs, such as the belief that understanding is of great value and worth pursuing, such beliefs are ones that serious inquirers will regard as evidently true.

Thus although total evidence skepticism is opposed to the blithe confidence about complex matters we may have felt in the absence of respect for the future, and so can be experienced as initially jarring or disillusioning, the vulnerability of the propositions it places in question is quite compatible with the intellectual safety of many others. We may have learned, through investigation in science, that we are still at the very beginning of organized inquiry on this planet, and that quite possibly there are many more - and also radically different and better justified - ideas to come, and this particularly in our most ambitious inquiries, focused on the more profound and complex matters. But we also see that a balance must be struck. The parameters of inquiry themselves require that we reject the idea that in our short time on the scene we have learned nothing of importance. How to strike the balance therefore should become an object of inquiry in its own right, replacing any alarm over the possibility of a descent into global skepticism (see Schellenberg 2013). ${ }^{\mathrm{vi}}$ 
Having said that, it does seem that the claim that theistic belief is justified by experiences apparently of God is going to be among the more vulnerable here. It certainly faces total evidence skepticism much more clearly than do the claims of the atheistic arguments I defended against skeptical theism in section I. Although there are plenty of questions about how and when such skepticism ought to be deemed applicable, it will be hard to deny that what seems most obvious to us upon reflection should be given a pass. And there don't seem to be any obvious-seeming truths in the neighborhood that the theist could turn to her advantage in the way that I have suggested the atheist may turn to her advantage certain apparent necessary truths about horrors and hiddenness.

If this assessment is correct, then although I have not insisted that any atheistic argument should convince the theist, we can use the very sort of skeptical reasoning against which we defended the atheist's right to believe his argument sound to argue that what does convince many a theist - experiences apparently of God - ought not to do so. Even should Rowe's argument or some other probabilistic argument from horrors or hiddenness fall to skeptical theism, such an event can be made the occasion of learning all-round when the atheist, in return, hands something like S4 to the theist and thus removes what may be essential grounds for her belief in God. Skeptical theism invites skeptical atheism.

\section{III.}

As just suggested, the atheism I defend arises in the context of total evidence skepticism and so (given my particular way of developing that skepticism) with an awareness of human immaturity in scientific time. And so we have another way of understanding that term 'skeptical atheism.' The seeming paradoxicality of this idea is erased when we notice that total evidence skepticism 
may be accepted for the purposes of deeper inquiry and so along with the aim to make what progress we can, even at our relatively primitive stage of development, by reference to (among other things) what seems to us most obviously true. The atheist will think her own position may represent such progress. But skepticism still marks the larger context in which she operates, if she behaves as I think she ought. Thus, for example, my sort of atheist will note how much more ambitious metaphysical naturalism is than atheism, and how many interesting options are ruled out if one is a naturalist. And so she will not immediately endorse naturalism along with her atheism. Hers is an investigative atheism, not the sort of reactionary atheism that is unfortunately all too common in our culture today, which is as firmly wed to naturalism as many theists are to theism, reacting to the latter from a prior commitment to the former. ${ }^{\mathrm{vi}}$

Against this background I will be understood when I say that an investigative atheism may take some interest in showing how the skeptical theistic way of reasoning, brought into the larger flow of total evidence skepticism, can be used to expose certain additional sources of doubt about theism sufficient to prevent overhasty migration to theism on the part of those left unconvinced by atheism. Moreover, and more positively, it can be used to inspire a greater openness to new religiously-relevant investigative results in the future. With these thoughts in mind, let's add two more skeptical theses to our list:

S5 We have no good reason for thinking that the arguments from horrors or hiddenness against theism we know of are representative, relative to the property of (potentially) constituting a successful proof that theism is false, of the arguments from horrors or hiddenness against theism there are. 
S6 We have no good reason for thinking that the possible goods we know of are representative, relative to the property of consistency with a person being axiologically ultimate, of the possible goods there are.

Unlike S4, these two theses are not theism-friendly: good reason to believe theism true is good reason to believe that the arguments from horrors and possible goods we know of are representative (in the relevant senses) of the arguments from horrors and possible goods there are. So the theist will say that we have to show that he lacks good reason to believe theism true before we can expect him to go along with S5 and S6. Now if the 'good reason to believe theism true' that the theist takes himself to have depends on religious experience in any way, then perhaps we have already done so. But my main purpose here is to show what atheists can do for investigation in philosophy by defending atheism in a context where certain skeptical theses are also defended, and for that purpose no judgment on this matter is needed. So while here noting this consequence of our work in the previous section, I shall from here on disregard it.

Suppose, then, that we are engaging someone who is left unconvinced by atheistic reasoning and wondering what to make of theism - someone, moreover, who accepts S1-S3. I suggest that, when presented with S5 and S6, she will realize that there is no non-arbitrary way of discriminating between the matters addressed by these propositions and those addressed by S1$\mathrm{S} 3$ in relation to what we have reason to believe. If we are cognitively limited in a way that would make the first three propositions true, then the fifth and sixth are true as well: the cognitive limitations in question affect all the matters under considerations here if they affect any. But what S5 and S6 represent are some new sources of at least doubt about theism. What 
this means is that with a skeptical theistic sort of reasoning, our questing non-theist has just been provided with good reason to remain a non-theist.

\section{$\underline{\text { 55 }}$}

Consider how this works in the case of S5. We easily assume that all of the relevant arguments in this or that domain have already been made, and that new authors, striving for innovation, just end up recycling old moves. This is a rather cynical view - one that is, I think, belied by the facts. However that may be, it seems clear that any non-theist impressed by skeptical theism, given even the apparently modest skepticism of S1-S3, is in no position to endorse it in relation to hiddenness or horrors. If S1-S3 are correct, then the cynical view is false for those domains, for then there may well be unknown facts about value or modality enabling deductive arguments from horrors or hiddenness to be made that would strike us as very novel and also as sound, even if all previous efforts have left us unimpressed. How could this be denied, if indeed we are in dark about the subjects in question? Perhaps what we are in the dark about is just what would enable such arguments to be made. If significant goods and evils and logical connections might be unknown to us, then we cannot legislate which way their implications would point. Then it might be that, were we to have a God's-eye view of such things, what we would see is that there is no good providing a morally sufficient reason for horrors, or that hiddenness entails the absence of some good (or the existence of some other evil) that would certainly be present (or absent) were there a perfectly good and loving God. Imagining what a God might see is indeed helpful here, as skeptical theism suggests, though what a God might see - it would have to be from some other possible world! - is that there is no God. 
Someone lacking independent reason to believe in God may of course think that such arguments as I defended in section I themselves illustrate how new investigations can reveal novel and sound arguments from horrors or hiddenness. But my main point here is that even if she does not think this, or even if she ceases to think this, the skeptical theistic form of reasoning can, ironically, be used to show that she should remain a non-theist.

\section{$\underline{56}$}

Let's consider next the link between skepticism about value of the sort promoted by S1 and the skepticism of S6. Since the latter skepticism may seem a bit unusual, and since it is tied up with what might be called the positive message of skeptical atheism, which can easily go unheeded, I propose to consider it somewhat more fully.

If there might be a good quite unknown to us that, were we to become aware of it and see things clearly, would strike us as providing a good reason for God to permit horrors, then our picture of value must be very partial indeed. Our understanding of value-related facts might have to be completely reconfigured to accommodate such a good - if an unsurpassably good and loving person would have a good reason to permit millions of horrors over a period of many millennia then the realm of value must be very strange. But then there is no non-arbitrary way for our non-theist to deny that she lacks good reason for thinking that a Divine reality would be a person in the first place. For if the realm of value might be that strange, then our understanding of value ultimacy might be mistaken. Then the greatest possible value - which is what I am taking axiological ultimacy to entail - might seem very strange to us too.

There is another way of getting at this point. We have no good reason for thinking we can 
identify what has the greatest possible value if the most fundamental truths about value might be out of reach for us. The most fundamental truths in any domain obviously have a bearing on all the others, and might here be expected to determine how 'greatest' or 'least' in matters of value come to apply. And it seems that the most fundamental truths about value may be obscured, and indeed the most deeply obscured of value truths, if skeptical theism is on the right track about value. Now perhaps we could know the deepest truths about value even if many other significant value truths were entirely beyond our ken, but the skeptical theist will surely have a hard time convincing us that we do: if some significant value truths might be beyond our ken because of relevant cognitive limitations, then the deepest might be beyond our ken too. Consider only how so many investigative enterprises have floundered for want of the most fundamental truths in their domain - or because of regularly changing views on what these are. Even the delivery of more fundamental truths would please many inquirers! Take, for example, physics. Physicists would be very happy if they found truths that unify quantum mechanics and general relativity, and they might consider themselves to have done so even while remaining doubtful as to whether they had struck absolute bedrock explanatorily. The claim to know the most fundamental truths in some domain is generally the most ambitious claim one can make. Thus if anything should come under the glare of value skepticism on account of our cognitive limitations, surely it is the suggestion that one has accessed the most fundamental truths about value. But then without the immunity to skepticism about such matters that a theist may take herself to have, our non-theist is stuck with the consequent of the conditional mentioned at the beginning of this paragraph, which says that we are in the dark about what would instantiate the greatest possible value.

Now if we are thus in the dark, then even if the possible goods we know of are consistent 
with some characterization of axiological ultimacy, we have no good reason for thinking similarly about the possible goods there are. (Notice how modality comes into play here along with value.) It follows that even if the possible goods we know of are consistent with a person being axiologically ultimate, as perhaps most theists and non-theists today would affirm, we have no good reason for thinking that the same is true of the possible goods there are. Despite what the goods we know of seem to indicate, there may, if we are in the dark about the greatest possible value, be unknown goods belonging to axiological ultimacy that no person could instantiate. And, of course, this is just as S6 would have it. ${ }^{\text {viii }}$

Now perhaps the skeptical theist will wish to relieve the non-theist of such doubts. What options does she have? Well, perhaps it will seem that even if theism can't properly be used by the non-theist to ground a deductive inference to the conclusion that S6 is false in her own case, some other proposition can be thus employed - and can be thus employed while still leaving S1$\mathrm{S} 3$ in the clear. It may, in particular, seem to the skeptical theist that it is just evident that no nonperson could be axiologically ultimate. One skeptical theist, Peter van Inwagen, actually claims as much in his recent Gifford Lectures. As he puts it: "I myself would say, without the least immodesty, that I am greater than any possible non-person - simply because I am a person" (2006, p. 158). Just what van Inwagen is claiming here is a bit unclear since he doesn't wish to give an analysis of the concept of a person. Intending only to "fix the concept," he says this: "By a person, I mean a being who may be, in the most straightforward and literal sense, addressed - a being whom one may call "thou"' (2006, p. 20). But it seems clear that he and other skeptical theists who hold that no non-person could be axiologically ultimate would be willing to fill out this explication in terms of the presence of beliefs, desires, values, rational capacities, and so 
forth, if only because these are things van Inwagen will surely mention if asked to explain what makes him a person and thereby makes him greater than any non-person, and because these are properties presupposed by the properties of omnipotence, omniscience, omnibenevolence, and so on as understood by traditional theists, who invariably ascribe them to God. So let us assume that this somewhat enlarged depiction of a person is applicable here. I will also assume that personal qualities are defining qualities, in the case of God, in such a way that no other properties God may possess are more fundamental - no other properties subsume the personal ones either explanatorily or evaluatively. This seems required by the notion that God is a person, which implies that the most fundamental features of Godhood are personal ones.

On these assumptions, what is to be said for the claim that it is evident that no non-person could be axiologically ultimate? van Inwagen himself admits that what we have here is a "substantive metaphysical thesis" (2006, p. 158). As such, it is hard to see how a skeptical theist could be justified in regarding the notion as evidently true. It is, of course, a notion very familiar to us, presupposed in much western religious thought. But anyone who recognizes such facts about our place in time as I mentioned earlier, and who thinks, within this frame of reference, about how we in the west are only now starting to acquaint ourselves with non-theistic religious thought, will regard the observation about familiarity as damaging to the case a skeptical theist is here required to make rather than helpful. Add to this what we are just now beginning to learn from the fledgling field of study known as the cognitive science of religion about how evolution may have predisposed us to find agency especially significant in matters religious (Barrett 2004, Boyer 2001, Tremlin 2006), and we will conclude that it would be wise to back away from the claim that it is just evident that only a person could be axiologically ultimate. Here it is also 
important to remember that the idea that a non-person could be axiologically ultimate need not deny that personal qualities (or properties analogous thereto) would necessarily have some place in an ultimate Divine reality. Perhaps they are allotted a lesser role in some larger mix defined by valuable properties of which we have, as yet, no inkling (Schellenberg 2009, 2013). Against this background, the idea that an axiologically ultimate reality evidently could only be a person must seem quite evidently unavailable to a skeptical theist seeking to remove, for non-theists, the new source of doubt about theism represented by S6.

For some this new source of doubt may be disquieting. But within the context of a total evidence skepticism sensitive to our place in time it may easily come to appear exhilarating instead. Of course if what seems most important to us is that we figure everything out, as swiftly as possible, or if a central aim of ours is to protect an understanding (perhaps theistic, perhaps naturalistic) that we've already arrived at, then such doubt may not seem very attractive. But if we allow our imaginations to linger in the thought of an understanding of the world beheld by finite beings but so magnificently deep that all our present thinking, even if it contains much truth, is just the tip of the proverbial iceberg, we may be attracted to a different stance. In any case, it seems clear that skeptical reasoning of the sort employed by the skeptical theist can be used to show that, whatever the religious diversity displayed by the world as we know it, much deeply significant religious diversity may not yet have come to light. Because of our early place in time, we need to be open to the possibility that our best religious ideas - including our best ideas about what is axiologically ultimate - are still ahead of us. This is the positive message of a skeptical atheism, a message designed to stir us from our complacency and prompt us to begin a deeper investigation into things Divine. 


\section{IV.}

So what options are open or live for skeptical theists who accept my arguments - if any such there should be? Well, if the arguments of section II are accepted, then of course a wider religious skepticism might be expected to replace the skeptical theist's theism. But I imagine this outcome will, at least for the time being, be resisted by theistic philosophers. I expect there will be opposition to the skeptical atheist's attempt to show that the skeptical theist is 'hoist by his own petard.' What success might attend such efforts only time will tell. The skeptical theist might also rightly point out how an examination of the consequences of theism for a wide array of philosophical and religious problems, presently being undertaken by, for example, Christian philosophers in America, can make for an investigative theism. This is certainly true, and I can imagine a scenario in which skeptical theists and skeptical atheists, both investigatively minded, together enlarge our field of vision on many matters that are or ought to be under inquiry. But if the fuller doubts that I have argued should come with skeptical theism eventually take hold, then a much stronger emphasis on non-theistic pictures of the Divine (or on non-theistic fillings for ultimism) might be expected to appear in western philosophy of religion. After all, we have devoted centuries and millennia of intense effort to the exploration of theism. One wonders what might come of a few millennia of equally rigorous attention to non-theistic ideas, both known and (presently) unknown.

There is also a very different alternative for skeptical theists that at least deserves mention. Seeing that whatever supports such theses as S1-S3 supports, in the right circumstances, S4-S6 as well, the skeptical theist might regard this as providing what amounts to a reductio for the former theses and so come to reject them. Of course, this would mean rejecting skeptical theism, too, but it is certainly one of the responses a theist might make. 
Someone who responds in this way will perhaps be inclined to say: "You're right - if I accept the first three theses on the grounds that make them attractive, then I should find myself drawn to the other three as well. But on reflection it seems to me that the other three are false and this even while leaving the possibility of an inference to their falsehood from a prior conviction that theism is true entirely to one side! I can use what I presently know about value to rule out a non-personal Ultimate, and I can infer from careful research into available arguments from horrors and purported defeaters of religious experience as justification for theistic belief that no such arguments are successful. Thank you for helping me to see this clearly. Of course, now I have to write William Rowe a letter of apology - and maybe also send one to all those journals that have published my papers on skeptical theism...."

I suspect that few skeptical theists will experience such a sudden conversion. But what we see here is still a way of responding to the arguments of this paper. I do not believe that it is the best response, but if on reflection it seems the right move to make, then our skeptical theist can avoid the feasible response I myself would promote, which means giving up theistic belief. Of course, to make it, our skeptical theist must cease to be a 'skeptical' theist. And I would suggest that if she wants to avoid giving up 'theist' too, she had better start writing papers on theodicy fast. $^{\text {ix }}$

\section{Notes}

i.Skeptical theism began with a focus on the problem of evil. But its defenders have recently sought to extend it to the hiddenness argument - see Bergmann (2009).

ii.This statement of Bergmann's three theses is in some places fuller than his, but the additional 
material comes right out of his explanation of how the term 'representative' is to be taken. (See Bergmann 2001, 2009.)

iii.I believe they also provide justification for a conversion from theism to atheism, but I will not argue for this claim here.

iv.It seems unlikely that S1-S3 can be accepted by the atheist compatibly with his accepting the moves in atheistic reasoning I have described. What the atheist will conclude, if the incompatibility obtains, is that what his moves give him reason to believe makes S1-S3 false in his case. But, of course, even then he can go along with a more general caution about how much one should claim to know in matters of value and modality.

v.I owe these terms to discussion with Paul Draper.

vi.A tempting thought that needs to be avoided as we seek such a balance is that the further our questions are from matters of pressing human concern, the less we should expect to know about them. As Martin Rees points out (2012), some of the best understood subjects concern celestial objects existing far from 'where we live,' and some of the least well understood, such as the best diet or how to predict and control the weather, are quite 'close to home,' affecting our lives in obvious ways.

vii.It is important to note here the epistemic asymmetry between atheism and naturalism. Atheism makes only the negative claim that there is no person-like Divine. This has many fewer metaphysical consequences than the positive claim of naturalism, and so is much less profound. 
Think also of the relative number of alternatives to theism and naturalism - the number of different ways in which these propositions can be false. Specifically, naturalism has many more alternatives than atheism, all of which must be false if it (naturalism) is true. Similar points arise in a comparison of atheism and theism. And so it will not be surprising if atheism does much better in a context of total evidence skepticism than either of the other propositions. Here it may also be useful to notice that if the existence of God requires that there be a person who is all powerful, all-knowing, all good and all loving, as well as the creator of the universe, then theistic arguments have the task of showing that all those conditions are satisfied. But an atheistic argument need only show that one such condition is not satisfied. For such general reasons as these, atheists may be expected to have an easier time than theists resisting total evidence skepticism.

viii.It may be thought that there is an important distinction between 'greatest possible reality' and 'greatest possible being' that is relevant here. Perhaps the theistic God realizes the latter property while not needing to realize the former. Suppose this is so. It poses no problem for the argument, which can be phrased, without loss of plausibility, in terms of either property.

ix. My thanks to Paul Draper and Steve Maitzen for comments on an earlier version of this paper.

\section{References}

Alston, William, Perceiving God: The Epistemology of Religious Experience (Ithaca: Cornell, 1991) 
Barrett, Justin L., Why Would Anyone Believe in God? (Lanham: AltaMira Press, 2004)

Boyer, Pascal, Religion Explained: The Evolutionary Origins of Religious Thought (New York:

Basic Books, 2001)

Bergmann, Michael, 'Skeptical Theism and Rowe's New Evidential Argument from Evil,' Nous 35 (2001), 278-296

Bergmann, Michael, 'Skeptical Theism and the Problem of Evil,' in The Oxford Handbook of Philosophical Theology, ed. Thomas P. Flint and Michael C. Rea (New York: Oxford University Press, 2009)

Plantinga, Alvin, Warranted Christian Belief (New York: Oxford University Press, 2000)

Rees, Martin, From Here to Infinity: A Vision for the Future of Science (New York: W. W. Norton, 2012)

Rowe, William, 'The Problem of Evil and Some Varieties of Atheism,' American Philosophical Quarterly 16 (1979), 335-341.

Schellenberg, J. L., The Wisdom to Doubt: A Justification of Religious Skepticism (Ithaca: Cornell University Press, 2007) 
Schellenberg, J. L., The Will to Imagine: A Justification of Skeptical Religion (Ithaca: Cornell University Press, 2009)

Schellenberg, J. L., Evolutionary Religion (Oxford: Oxford University Press, 2013)

Tremlin, Todd, Minds and Gods: The Cognitive Foundations of Religion (Oxford: Oxford University Press, 2006)

van Inwagen, Peter, The Problem of Evil (Oxford: Clarendon Press, 2006)

ix 